\title{
A place to share: Some thoughts about the meaning of territory and boundaries in our thinking about God and humanity
}

\author{
Riet Bons-Storm (Groningen) ${ }^{1}$ \\ Research Associate: Department of Practical Theology \\ University of Pretoria
}

\begin{abstract}
This article proffers some thoughts in reply to the following question: how can we think about God in a theology that takes into account the concept of place in such a way that we are able to live together in a salvific way with others, sharing a place as equals? Concepts such as "territory" and "territoriality" are helpful, because they can be linked with "identity" and the need to feel safe. Boundaries and boundary markers such as walls play an important role in conflicts. The possibility of a "liminal space" at a boundary where eye-to-eye relationships may be possible helps to make "the other", the stranger, a human being with her/his own needs and vulnerability. Using the Israeli/Palestinian conflict as an example, images of God and their impact on the possibility of sharing the land are explored. Hagar, herself a stranger, experiences God's lifesaving attention and names God "God of seeing".
\end{abstract}

"We must recognize that our views of God are not in themselves so tremendously important. What is decisively important is the dynamic developed by faith, the way it has an effect on world history."

(Gerstenberger 2002:305)

\section{A CORE ETHICAL CHALLENGE: A PLACE TO BE SHARED}

The stretch of land on the eastern shore of the Mediterranean where the state of Israel has established its authority is intersected by a wall that winds its way among the hills, through the olive groves, the villages, cutting off and blocking

\footnotetext{
${ }^{1}$ Prof Dr Riet Bons-Storm is Emeritus-Professor at the University of Groningen (The Netherlands) and a member of the International Advisory Board of HTS Theological Studies. She is a research associate of Prof Dr Yolanda Dreyer, Department of Practical Theology, University of Pretoria.
} 


\section{A place to share: Some thoughts about the meaning of territory and boundaries}

even main roads. Nine metres high and many kilometres long, with barbed wire on top, it towers over the land, always built on land where Palestinians live. An almost unbelievable sense of threat emanates from the massive grey concrete structure. At a physical level, Jews and Palestinians can no longer see each other. At every level, they become strangers to one another, more than they have ever been before. Communication is made impossible. The gates in the wall are guarded by very young Israeli soldiers, mostly immigrants from Ethiopia. Guns at the ready, they walk around, sometimes high above people at ground level, as the soldiers move on catwalks. To pass through the gates, Palestinians must face hours of frustration and of intimidation. Walls dominate the land of Israel.

For both groups of people, both Jews and Palestinians, the land is vitally important. It is the place where they belong, the place of their history, with all its emotions, positive and negative - the land of their roots, the land of hope for their children. Both groups regard this land as being connected to their God. In precisely this place, and all the more intensely in Jerusalem, they are aware of their faith. This place nurtures their faith in God and in their future. They look at this land as a holy place. Both groups live by their own narratives about their entitlement to live there. According to these narratives, they are the children of Isaac or of Ishmael, sons and daughters of Sarah or of Hagar. Although they believe that they have the same father, they live as enemies.

In my own country, the Netherlands, there are no visible walls between groups of people, but there are invisible barriers. More and more, the street becomes a place where people fight these barriers, resulting in violence. Indigenous Dutch people claim "their" street. It used to be so quiet and peaceful, they say. And ... is not the whole country rightly theirs? "Strangers" - people from the Middle East whose fathers were invited to come to the Netherlands as workers in the 1960s and 1970s, people from the former colonies of Surinam and the Antilles (who therefore have full Dutch citizenship), and refugees from everywhere in the world claim the street as well. In the street, the violence that smoulders in numerous places in society erupts. Then it becomes obvious that indigenous and non-indigenous Dutch deny each other the right to be there.

Many indigenous Dutch people have a deep attachment to their small, densely populated country. They see themselves as hard-working, freedomloving people. The narratives of their national history tell them that they fought a big country, Spain, to gain their freedom in the sixteenth and seventeenth centuries; and that they wrested their land from the sea with their own hands.

The Netherlands is a secularized country, but many Dutch people nevertheless join heartily in singing the sixth verse of the national anthem: 
"Mijn schild ende betrouwen zijt Gij, o God mijn Heer" ["You are my shield and trust, oh God my Lord"]. For nearly all Dutch people, it is quite self-evident that a national church service is held on the eve of Liberation Day, 4 May.

Consciously or subconsciously, many indigenous Dutch people feel they are entitled by a Divine right to live in their country, to own it. They are Dutch and as such they have a rooted identity that they can be proud of.

"The Netherlands is full!" right-wing political parties shout, and many agree with them. However, the Dutch have to share their country, their land, their streets, with others. In the streets, suspicion and hostility are born in the clash between cultures and religions (Gopin 2002:21 ff), because this public space has to be shared.

Human beings need a safe place, a space they feel entitled to live in. In her autobiographical novel My Place (1978), indigenous Australian Sally Morgan illustrates how important such a place is. The novel describes Sally's quest for "her" land, the land of her family group, now occupied by white settlers for more than a century. These settlers claim that they have a right to live there.

John Inge (2003) largues that place, vital as it is for humans, is not an important item in theology. He argues that time plays the leading part, for instance, in thinking about the longing for the Kingdom to come. Nevertheless, place moulds our experience as embodied creatures in a very significant way. The importance of place is shown in the many ways in which it is expressed in figures of speech or idiomatic expressions, for instance, "to know one's place" or "the place of women in society". Place in the literal sense refers to a particular part of the earth's surface and it is necessary for an embodied human being, so that she/he has somewhere to stand on, to live on. She/he needs part of the surface of this earth to survive. On some part of the earth, she/he needs to feel entitled to inhabit some room: she/he needs a "territory". If that is denied to a person, she/he is nowhere, she/he is nobody.

Nevertheless, human beings move about, they travel and cross boundaries. When they do, they become strangers in some other place. Abraham can be regarded as the prototype of the stranger. Mobility has increased a lot since Abraham's time. Nowadays, there are a great many strangers: they are tourists, guests, immigrants, "expats", colonists, soldiers, refugees: none of them are in their own place; they share the place of others, for better or for worse.

In this article I suggest some thoughts about the question of how we can think about God in a theology that takes into account place in such a way that we are able to live together in a salvific way with others on this earth. It seems to me that Christian ethics, however complicated they may be, often 


\section{A place to share: Some thoughts about the meaning of territory and boundaries}

boil down to this "sharing of a place in a salvific way". In the article, I explore the meaning of territory and of boundaries and the relationship of God to place.

\section{TERRITORIALITY AND BOUNDARIES}

In 1973, the Dutch/North American psychologists Cornelis B Bakker and Marianne K Bakker-Rabdau wrote a book that greatly clarified human relations, No trespassing (I used the Dutch edition, Verboden toegang). They use the term "territoriality" as a tool to understanding people and the way people relate to each other. They contend that territoriality "permeates every aspect of human existence. Constantly a person divides everything in categories of possession: my and your, his and her, our and their. This territorial index helps him to evaluate himself in relation to others and serves him in times of conflict" (Bakker \& Bakker-Rabdau 1973:50). Being territorial means being defined by a territory. A territory is that part of the physical or cultural space in which a person feels entitled to live. She/he needs grounds for this entitlement and finds them, for instance, in the sacred texts of a religion, either written (e.g. in the case of the Israelis and Palestinians) or retold from generation to generation and transmitted via an oral tradition (as in the case of the Australian Aboriginals). Narratives about the history of a place can also give a strong justification of territorial claims, as it does for many Dutch people. As long as such a "justification" is believed to be true, a particular group's claim on a territory can remain strong.

Because human beings feel that they need a territory, they tend to define and guard the boundaries of whatever territory they have taken possession of. Others may be let in, but only on conditions set by the owner of the territory. Inside the boundaries of a territory, the person it belongs to can feel free to be what she/he is. She/he can feel safe, which is very important. She/he is entitled to defend her/himself against invasions. All human beings develop strategies to guard their territory; and aggression is often seen as the best defence. When it comes to territoriality, aggression can also be used in an endeavour to enlarge a territory and annex (part of) someone else's territory. Neighbours very easily become enemies. If one does not feel strong - or is not regarded as strong in a culture - compared to possible invaders, the strategy for safety can be to minimize one's territory and let the (aggressive) other in without violence, as far as it is still possible to survive in what remains of the territory. The smallest territory one can inhabit is one's own body. Rape is an invasion and annexation of that minimal territory and consequently reduces a raped person to nobody. 
In addition to stressing the importance of a physical territory, Bakker and Bakker-Rabdau (1973) point out the significance of territory in a sociocultural sense. The sum of a person's leading ideologies or religious convictions, expertise and special skills, can also be understood as the person's territory. This is the domain where a person is convinced that she/he is entitled to take decisions and implement them. Territoriality as such is therefore formative for a person's sense of identity.

Most of the conflicts between people can be interpreted as battles about the boundaries of their territories. This applies to conflicts in relations between partners, in marriages or in families, but also between groups. The Israeli author Amos Oz calls the Israeli-Palestinian conflict "no war between religions, no war between cultures, but simply a dispute about real estate" (Oz 2004:7).

The North American psychologist Ruthellen Josselson (1996) contends that every person does indeed need a territory and she pays a lot of attention to boundaries. What makes people use their gifts and limitations in the most positive way is the experience that these boundaries match their potential, do not restrict them and give them a sense of safety and security that nurtures healthy self-esteem. Such a healthy sense of self-esteem, based on a person's possibilities and limitations, provides the best opportunity not to spend too much effort on fortifying boundaries. They can stay low, transparent supplied with gates. If a person feels safe enough, it is possible for her/him to share a reasonably large part of her/his personal territory with another person who respects her/his need for self-esteem. If this sharing occurs, the partners come to feel "embedded", as if they have "a we to claim" (Josselyn 1996:178). It shapes the conviction of being entitled to inhabit a piece of this earth as a person with gifts and limitations, but at the same time being a partner in a larger domain, or another domain, belonging to a group or another person that acknowledges one's identity - one's personal history included - as one of its own.

Josselyn (1996:98) stresses the importance of eye-to-eye contact across boundaries: "In eye-to-eye relating is the recognition that we have meaning to others." In order to make this contact possible, boundary markers such as walls have to be permeable and supplied with gates. To lessen the ever-present possibility of conflicts arising at boundaries, people who are "strangers" to each other (even a neighbour or a friend, even a lover, is a stranger in the sense that she/he inhabits a different personal territory) have to seek possibilities to "see" each other, to see the "stranger" as an embodied person, vulnerable, always ready to defend her/himself with or without violence. 


\section{A place to share: Some thoughts about the meaning of territory and boundaries}

Spanish theologian Mercedes Navarro (2003) also highlights boundaries as a concept. At the boundary, she contends, "liminal space" is possible. At boundaries, where confrontation, competition and violence so easily occur, a virtual no-man's-land can be imagined. This liminal space gives people from or with different territories the possibility of thinking about their own identity and that of the other. There they can seek opportunities to "see" one another, to suspend for a moment the exclusiveness of the different ideologies and value systems that validate the entitlement to each territorial claim. In such a liminal space, the founding narratives for these claims can be told and critically examined, and openings to a shared narrative can be explored.

\section{GOD AND TERRITORIALITY}

Walter Brueggemann, an Old Testament scholar, was one of the first to focus on the preoccupation with place in the Bible. He contends that, in the Bible, place figures as a primary category of faith and that land is a central theme. Not meaninglessness, but rootlessness is the greatest threat for a human being (Brueggemann 1978:4). His argument reminds me of Mary Phil Korzak's translation of Genesis At the start ... (1992). She translates the Hebrew term haadam with "the groundling". All other translations I have looked at simply translate the Hebrew term with "man". But Adam, the prototype of all human beings, came from the earth and would in time return into the earth, and he needed a piece of the earth to live on during his life. He had to share the earth. God gave him Eve, blessed both of them and said: "Be fruitful, increase, fill the earth..."

The problems about sharing a territory, nowadays often painfully experienced in a great many places, become particularly embattled in what is called "the Holy Land". The conflicts there have repercussions in the whole of the Middle East and indeed in the whole world. I focus on these conflicts as an example of an endeavour to think about God and territoriality.

The Old Testament text plays an important role in the conflict about the possession of "the Holy Land", Israel/Palestine. Jews have a firm conviction that this piece of the earth is the Promised Land, promised to the Jews to dwell in, exclusively. According to their exegesis of the Tanak (Old Testament). God gave this place to the Jews as their territory. This religious vindication, justifying silent or aggressive immigration into a land inhabited by other people who call it their place is made stronger by a claim of the Jews that they are entitled to compensation for their deprivation of a territory for centuries on end, more than once. This deprivation was made even more 
burdensome as they became strangers in the most negative sense: Jews were despised, forced to be slaves, isolated in small ghettoes, tortured, raped and murdered by the millions. They experienced, in body and soul, what it means to be the stranger. Everybody with a heart wants to justify the Jewish claim to Israel as a territory of their own, but everybody who thinks further becomes very uneasy. Is God willing to give the Jews a territory at the expense of others? Are the others, the ammim, the goyim, the other peoples, Palestinians included, of lesser value in God's eyes?

Jewish writer Marc Gopin states that a key category in thinking about the exclusive claim of the Jews to the land is chosenness (Gopin 2002:13). He contends that meaning has to be given to this category in the context of the narratives in which it is used in the text which is the context of a family myth. Gopin (2002:8) explains: "I use 'myth' in the sense of a story that contains some ultimate and enduring truth, and a way of making sense of amorphous reality, for those who believe in it." A shared myth allows big conflicts to be understood by the human mind and absorbed by the human heart (Gopin 2002:8). The Hebrew biblical myth is a narrative about the ups and downs of a family, Abraham's family. Abraham is called av hamon goyim [father of many peoples]. And indeed, Abraham did have more than one son - his first child was Ishmael (by his second wife Hagar) and his second son was Isaac (by his first wife Sarah). In Genesis 25, the sons of another wife, Ketura, are also mentioned. The main hermeneutics of the biblical narrative about this family developed a myth that made it impossible for the offspring of the two sons to share Abraham's estate after his death. "In Jewish rabbinic interpretation, Isaac is the key to Jewish lineage, Ishmael to Arab and Islamic lineage, and Esau, Jacob's brother, is the key-symbol for Roman/European/Christian lineage. The separation of these three relatives - and their animosity - is the key to the rabbinic mythical account of later history and their tragedies" (Gopin 2002:9). The stories about Sarah and Hagar in Genesis 16 and Genesis 21 reinforce the claims of Isaac as the legal heir of his father. We hear stories of rivalry between two wives and of life-threatening measures taken to safeguard Isaac's rights. In these stories Sarah speaks and acts as somebody who is in charge. Hagar is a stranger, an Egyptian servant. Sarah's words and Abraham's consent turn Hagar into a helpless victim. The key event in the story is that Hagar and her son are expelled, sent away into the desert. Abraham gives them some provisions for the road, but they are insufficient. Ishmael nearly dies.

But into this family drama enters another figure: the messenger of God. This messenger opens Hagar's eyes to a well, to the possibility to survive. Hagar is convinced that God has seen her and has saved her and her son's 


\section{A place to share: Some thoughts about the meaning of territory and boundaries}

life. She, the stranger, gives a name to God, a name like every true name for God, born from her experience with God. "You, God of seeing, for she said: have I not seen also after He saw me?" (Gn 16:13 in the translation by Mary Phil Korzak 1992). According to Genesis 16:18, Abraham gives their son the name Ishmael: "God hears". It is clear that the text favours the rights of Isaac to inherit the land, but also shows that God does not abandon Hagar and Ishmael. The texts of Genesis do not separate them completely: according to Genesis 25:9, Isaac and Ishmael bury their father together. The text is ambiguous about the relationship of these two brothers, but its interpreters are univocal in seeing them as rivals. Isaac's sons are seen as God's favourites, the chosen ones, entitled to live in the land, and they claim that only they have this right. The assumption is that a father cannot love both sons equally.

To understand things or human beings as equal does not fit into our usual way of thinking. Perhaps based upon children's deep psychological need to possess the love of their father (or mother) exclusively, or at least to possess their love in a very special and unique way, it is very difficult in our cultures to imagine that people can share a position equally (see Bons-Storm 2007:31-49). Perhaps it is therefore also difficult to think and act on the assumption that God can love Her/His "peoples" equally. But love, unlike any other thing I know, is a commodity that grows when it is given to more people.

Writing about the "promised land", Brueggemann contends that the narratives of the Bible acknowledge the human need to belong to a certain place, where the roots of a community are experienced and where its members can feel safe, empowered by the often religiously based conviction that they "belong" there. The land of Israel as the "promised land" fulfils this role for Jews, because for them it is a place alive with memories of experiences with their God. But this love for eretz Israel has its counterpart in the love for its territory of every group of people, for every nation. The uniqueness of the love of the Jews for the land of Israel lies not only in the emotional and religious experience the Jews have in relation to this particular place, but in its theological intensity (Inge 2003:37). This means that in the theological thinking of the Jews, as inscribed in their holy texts, they stress that they have had intense emotional and spiritual experiences with their God in this place. God and the Holy Land as their territory have become entwined.

The texts of Genesis may be ambiguous, but there are many texts in the Old Testament that clearly say that God has given the Holy Land only to the children of Isaac, for example, Joshua's speech to the tribes of Israel. Before he dies, Joshua gives the Israelites the founding story of their identity as the owners of the Holy Land as their territory, the land where they - the descendants of Isaac - shall worship God, the Eternal One. We read in 
Joshua 24:3: "And I took your father Abraham from the other side of the flood and led him throughout all the land of Canaan, and multiplied his seed and gave him Isaac."

Who is this God that, according to the religious conviction of many Jews and Christians, gives a certain group of people a land to invade, to conquer and to possess, at the expense of the people who already live there? In his book Theologies in the Old Testament (note the plural) E S Gerstenberger (2002) summarises opinions about the development of the God worshipped by the Israelites. His argument is not altogether new to theologians (even if it is for many lay people), but it has to be taken seriously when we think about the religious claims of the Jews regarding Israel as their territory: "In the Hebrew tradition, Yahweh, the warrior God, is quite clearly initially a tribal deity, only secondarily does he become the divine supreme head of the nation and also of the family" (Gerstenberger 2002:22). The preJahwistic tradition had many deities, male and female, all attached to a certain settlement or tribal region. The names of these deities live on in the names of towns: Anathoth must be connected with the goddess Anath; Kiriath-baal (Jos 15:60) means the "city of Baal". Based on the fact that there are only a few city names with "JHWH" in them, it may be assumed that JHWH was worshipped not as a city god, but as a tribal warrior god, who led his tribe into battle to defend its territory and, if possible, enlarge it (Gerstenberger 2002:101-102). This JHWH is a god of thunderstorms and earthquakes, as Judges 5:4-5 tells us. There was already a cult of JHWH in the pre-state period (Gerstenberger 2002:138), but the cult of JHWH as the only God, guaranteeing the identity of Israel as a nation with its own territory, dates back to the period of the kingdom(s) and the exilic and post-exilic periods. The verses of the "Hear Israel ..." in Deuteronomy 6:4-6 stress this cult of the One God. Gerstenberger (2002:274) concludes: "Israel may concentrate on its God, who has made his will known - that is a commandment for selfpreservation. It concerns the existence of the community of faith, not the existence of God. The exclusiveness of worship of Yahweh asserted here is important in this moment of the Babylonian captivity and in the overwhelming powerful world of the gods of the rulers". The exclusive claims of Israel as an ethnic group and as a state in eretz Israel could be based on a myth at whose centre $\mathrm{JHWH}$, the fearsome warrior god, became intertwined with the features of the national, exilic and post-exilic ideas about JHWH.

There is not only one image of God in the Old Testament or in the whole Bible - there are many. We do not know how or what God really is. However, we do know how different images of God work. People choose or 


\section{A place to share: Some thoughts about the meaning of territory and boundaries}

are inspired to choose a certain image that has consequences: either to the benefit of only one group of people, or salvific for all humankind.

Jesus is depicted as a person who experienced himself as being without a territory, a stranger himself (Mt 8:20 and Lk 9:58). He was expelled from society and killed. He chose to hear texts that speak about a God who does justice to Jews, but also to strangers, and who expands his love to all people.

\section{THE LONG AND STONY ROAD TO OPENINGS IN BOUNDARIES}

There are concepts in the Old Testament that disrupt the notion of God as the One who exclusively has the wellbeing of the Jews at heart: the stranger and all people.

Abraham, the Jews' founding father, was himself a stranger in a land where other people lived. Genesis 23, the story of Sarah's death and burial, shows Abraham as a humble immigrant without his own land, a "sojourner" asking the lords of the land for a place to bury his beloved wife. He acquired a field and a cave in the vicinity of modern-day Hebron. For a long time, the descendents of Abraham and Isaac lived among the peoples who were there before them. It is in the narratives of the Israelites returning from Egypt that they became invaders and conquerors, claiming the whole of the land in God's name. Being descendants of a stranger is perhaps a deeply buried and anxiety-laden part of Israel's common consciousness.

Still, a great many texts mention the stranger who has to be cared for in God's name. Deuteronomy 5:14 speaks of "the stranger within your gates". In Deuteronomy $24: 17$, for instance, the rights of the stranger are protected, just like those of widows. The Israelites are reminded, for instance, in Leviticus 19:33-34, of their own deprivations during their exile in Egypt. In other words, in the name of JHWH it is considered wrong to deny strangers a place to live because the Israelites are entitled to compensation for their suffering in Egypt, and during the Holocaust. In fact, according to the texts, the fact that they themselves have suffered must be the source of their compassion for others.

In many texts, "all peoples", all the humanity of this whole earth, are objects of JHWH's attention, love and redemption. A striking example is the prophesy in Isaiah 25:6: "And on this mountain shall JHWH of the armies make unto all peoples a feast of fat things, a feast of old wines, of fat foods full of marrow, of fine, long stored wines ...." 
Which image of God, with which biblical roots, could work in a positive way in the many conflicts about territories we see in our world? Hagar's faithexperience of God, El Roi, the God of seeing, the God of seeing the stranger, could well be the key to opening a way of thinking about God that can make little openings in the walls that defend our territories. The first and most important thing in relationships is to see the other. Josselyn (1996) stresses the need for eye-to-eye contact as the first step of a meaningful relationship across boundaries, as is argued earlier in this article. The act of seeing the other appeals to us in the embodied humanity of the other, perhaps threatening, yes, but also vulnerable. As long as the other is understood as fully human, there is still hope that this appeal might work: we can identify with the other, imagine her/his pain and frustration. If the walls are so high that this seeing is made impossible, as is the case with the walls erected by Israel on Palestinian land, there is hardly any hope left. If visible or invisible walls are erected and strangers are gathered in and restricted to ghettoes, Homelands, places they can hardly leave, there is not much hope for sharing a place in peace and justice.

The sharing of a territory - which is always physical, but also sociocultural - is no small thing; it needs a person to change her/his identity. In my country, for instance, Dutch people are no longer per definition white and (more or less) Christian. I have to reconsider my own identity.

The opening of gates to let the other in, hospitality, is an important virtue in the value systems of many cultures and religions, including Judaism, Islam and Christianity. On the basis of the acknowledgement that the other can feature in a positive way in one's founding myth and no longer needs to be seen only as the threatening other, the other can be let into one's territory, one's home, one's country. Hospitality encompasses more than tolerance. Hospitality is the practice of "loving one's neighbour". Hospitality is associated with seeing the needs of one's neighbour and fulfilling them. Hospitality is generosity (see Bretherton 2006:98). The need for a territory of one's own remains important, but, bearing in mind Josselyn's argument, as mentioned earlier, one can try to establish "a we". However, a guest is not supposed to stay too long and she/he is expected to adapt her/his ways to the ways of her/his host. Often the term "hospitality" does not cover the whole process of becoming co-inhabitants of a territory. In many places on earth, the problem is who is the guest and who is the host? Who has to adapt her/his ways to whom? Who is the main possessor of a territory? Who has the power to make the rules and, if it is deemed necessary, to expel the other? Who controls the means to survive in a place? 


\section{A place to share: Some thoughts about the meaning of territory and boundaries}

The question is whether the most important myths of competing groups make it imaginable to share a place with mutual respect. To continue the example of the conflict between Jews and Palestinians - some Biblical texts (as mentioned above) and texts in the Koran make it possible to imagine this. The Koran, Sura 49:13, says: "O mankind, We have created you of male and female, and have made you peoples and tribes, that you may become to know one another." Safa' Abu Assab, a Muslim scholar, took this text (in an unpublished lecture during the seminar about Sarah and Hagar, Jerusalem, 22 June 2006) as an opening for peace talks among Muslims, Jews and Christians. According to her, it is evident that it is most important for Allah that different people, as different from each other as male and female are, respect each other and see each other as co-human. If that is the case, as Mercedes Navarro argued, a liminal space can be imagined and used as a space for negotiations. In these negotiations, it "is vital that one has a hermeneutic of one's traditions that allows, at least sometimes, for both sides of a conflict to be wrong and right simultaneously. Only in this way can two rights coexist in different worldviews" (Gopin 2002:109, Gopin's emphasis). In other words, the partners in the negotiations make their leading narratives conscious and tell them to each other. In doing this, they look for overlap in their different myths of entitlement. Is it possible that an ideology is (partly) shared? Is it possible that the narratives and myths of the religion of the other can be listened to with patience and respect? Do both parties acknowledge each other's basic human rights? Do they acknowledge each other's wounds, inflicted during the course of history, and the pain causing what is perhaps an excessive need for security? Is it possible to forgive? Do they see the other as a human being and as such passionately longing for a territory of her/his own, for a grounded identity and self-esteem?

A (partly) shared narrative or myth is the basis for learning to live together in everyday life and for sharing a place in practice. Luke Bretherton, writing about the possibility of finding a salvific way to live and act as a community in today's increasing ethical plurality, recommends three steps on the path to living together as communities with different ethical systems, different systems of responsibilities, entitlements and accountabilities.

The first step is to focus on the local community where people actually have to live together. It is there that a possibility to see each other as human beings is the greatest. A "condition sine qua non" is that the different groups in the local community see the pain that conflicts inflict on both parties. They have to become conscious of the need to live together in peace. The second step is a "simultaneous renewal of emphasis on demonstrations of particular conceptions of the common good in practice". The third is "an engagement 
with the politics of local community, wherein the reform of practices and institutions can take place through rational debate between rival communities of resistance" (Bretherton 2006:99).

Taking these three steps may require a long time, but they are worth the effort. They always have to be taken by both parties, together, slowly, letting ideas ripen and old prejudices die. It is a way of making half-conscious religious myths and ideologies conscious, learning about the religion and ideologies, the history and the identity of the other, looking for interfaces or points of contact. And, perhaps, in time, the twain will meet in a shared place.

\section{Works consulted}

Bakker, C B \& Bakker-Rabdau, M K 1973. Verboden toegang: Verkenning rond het menselijk territorium. Antwerpen: De Nederlandse Boekhandel.

Bons-Storm, R 2007. Gezegend leven: Op weg naar een pastorale gemeente in een verbrokkelde wereld. Gorinchem: Narratio.

Bretherton, L 2006. Hospitality as holiness: Christian witness amid moral diversity. Aldershot: Ashgate.

Brueggemann, W 1978. The Land: Place as gift, promise and challenge in biblical faith. London: SPCK.

Gerstenberger, E S 2002. Theologies in the Old Testament. London: T \& T Clark. Gopin, M 2002. Holy war, holy peace: How religion can bring peace to the Middle East. Oxford: Oxford University Press.

Inge, J 2003. A Christian theology of place. Aldershot: Ashgate.

Josselson, R 1996. The space between us: Exploring the dimensions of human relations. Thousand Oaks, CA: Sage.

Korzak, M P 1992. At the start ... Genesis made new. European Series, Louvain Cahiers, 124.

Morgan, S 1987. My place. South Fremantle: Fremantle Arts Centre Press.

Navarro, M 2003. Women and religions: Visibility and invisibility in society in Southern Europe. Unpublished lecture, given at the European Women Synod in Barcelona.

Oz, A 2004. Hoe genees je een fanaticus? Amsterdam: De Bezige Bij. 